\title{
BMJ Open Five-year standardised mortality ratios in a cohort of homeless people in Dublin
}

\author{
Jo-Hanna Ivers, ${ }^{1}$ Lina Zgaga, ${ }^{1}$ Bernie O'Donoghue-Hynes, ${ }^{2}$ Aisling Heary, ${ }^{1}$ \\ Brian Gallwey, ${ }^{2}$ Joe Barry ${ }^{1}$
}

To cite: Ivers J-H, Zgaga L, O'Donoghue-Hynes B, et al. Five-year standardised mortality ratios in a cohort of homeless people in Dublin. BMJ Open 2019;9:e023010. doi:10.1136/ bmjopen-2018-023010

- Prepublication history and additional material for this paper are available online. To view please visit the journal (http:// dx.doi.org/10.1136/bmjopen2018-023010).

Received 22 March 2018 Revised 9 July 2018 Accepted 18 September 2018
Check for updates

(C) Author(s) (or their employer(s)) 2019. Re-use permitted under CC BY-NC. No commercial re-use. See rights and permissions. Published by BMJ.

${ }^{1}$ Department of Public Health and Primary Care, Institute of Population Health, School of Medicine, Trinity College Dublin, Dublin, Ireland

${ }^{2}$ Research, Dublin Regional Homeless Executive, Dublin, Ireland

Correspondence to

Dr Jo-Hanna Ivers; jivers@tcd.ie

\section{ABSTRACT}

Objective To calculate standardised mortality ratios (SMRs) for a cohort of homeless people in the Dublin region over a 5 -year period and to examine leading causes of death.

Setting Homeless services reporting deaths from homeless persons in their care across the Dublin Homeless Region.

Methods Death data among people who experience homelessness was acquired from the Dublin Region Homeless Executive (2011-2015) and validated from both death certificates and records from the Dublin Coroner's Office.

Participants Two hundred and nine deaths were recorded; of these 201 were verified $(n=156$ males, $77.6 \%)$. Deaths that could not be verified by certificate or coroners record were excluded from the study.

Results SMRs were 3-10 times higher in homeless men and 6-10 times higher in homeless women compared with the general population. Drug and alcohol-related deaths were the leading cause of death, accounting for $38.4 \%$ of deaths in homeless individuals. These were followed by circulatory (20\%) and respiratory causes (13\%).

Conclusion Mortality rates among homeless persons are exceptionally high. Services and programmes, particularly housing and those targeting overdose and alcoholism, are urgently needed to prevent premature mortality in this vulnerable population.

\section{INTRODUCTION}

Homelessness is a major public health concern. ${ }^{12}$ Excess mortality is associated with extensive social exclusion. ${ }^{3}$ Studies in the USA suggest that one fifth of persons experiencing homelessness will go on to become chronically homeless. ${ }^{4}$ The longer a person is homeless, the more likely it is that they will suffer from a medical condition, and chronically homeless individuals are far more likely to experience greater rates of chronic disease, and mental health issues ${ }^{5-9}$ and addiction. ${ }^{10}$ Indeed, homeless persons experience excessive rates of poor mental health and addiction compared with the general population. ${ }^{781112}$ Furthermore, Nielsen et al note that dual diagnosis, specifically schizophrenic

\section{Strengths and limitations of this study}

The first Irish study to examine standardised mortality ratios in a homeless person.

- A key strength is the high volume of verified deaths.

- The study provides evidence of disparity in mortality among homeless people in Dublin compared with the general population.

- A weakness is small number of the reported deaths provided to authors were unverifiable.

- The common weaknesses of a retrospective analysis on database information apply.

spectrum disorders coupled with addiction, is predictive of increased mortality among homeless people. ${ }^{8}$

Moreover, homelessness is associated with an increased risk of infections such as tuberculosis and HIV disease. ${ }^{13} 14$ Among the homeless, access to healthcare is often suboptimal. ${ }^{15} 16$ Nonetheless Fazel et al emphasise the systematic as well as individual factors that perpetuate homelessness. ${ }^{4}$ Homeless persons also experience severe poverty and often come from disadvantaged minorities, factors that are independently associated with poor health. ${ }^{16}$ Thus, suggestions that mortality among homeless populations is much higher than in the general population is not surprising.

Studies of mortality among homeless populations, mainly in the USA, ${ }^{17}$ Canada $^{18}$ and Europe $^{19-21}$ carried out over the past 20 years have found that mortality rates among the homeless were 3-13 times higher than rates in the general population. While the causes of deaths vary widely, the leading causes included cancers, cardiovascular diseases, accidents, intoxication and suicides. While these are similar to causes of death in the general population, they occur at very different rates. For example, despite the low prevalence of head and neck cancer in the general population is extremely low, however 
homeless people disproportionately suffer and die from head and neck cancers. ${ }^{22} 23$ Similarly, homicide and intoxication are among the leading causes of death in homeless populations. ${ }^{1724}$ As homeless people age the causes of death change. In a recent study Baggett $e t$ al examined changes in causes of death among homeless individuals over a 15 -year period in the USA. ${ }^{17}$ The authors found homicide was the leading cause of death among men who were 18-24years of age. AIDS was the major cause of death among those who were 25-44years of age; heart disease and cancer were the leading causes of death in persons who were $45-64$ years of age. ${ }^{17}$

Despite the persistence of homelessness in Ireland ${ }^{25-27}$ the past decade has yielded no studies on mortality among the homeless and information on causes of death in this population is sparse. Internationally the majority of studies have been conducted in the USA and Canada. Fewer have been carried out in Europe. There is a consensus within the literature that homeless deaths are significantly underestimated. ${ }^{28}{ }^{29}$ Several studies identified the need to understand homeless mortality better, particularly the leading causes of death, ${ }^{8}$ in order to manage this issue and to implement effective strategies to decrease the number of homeless deaths. ${ }^{28} 29$

The aims of the current study are twofold: (1) to calculate mortality among the homeless population in Dublin (2) to describe the leading causes of deaths among this population.

\section{METHODS}

The study is a retrospective record study of homeless deaths between 2011 and 2015. The Dublin Region Homeless Executive (DRHE) is a shared service for all four local authorities in the Dublin region. It operates under the aegis of Dublin City Council as the lead statutory authority in the region and is responsible for the implementation of regional action plans, plans mandated under the Housing (Miscellaneous Provisions) Act 2009. It coordinates responses to homelessness primarily through the provision of funding to 23 non-profit homeless service providers operating 102 services in Dublin, the assessment and placement of persons into these funded services by local authority staff and through sourcing and allocating tenancies for persons experiencing homelessness. In March 2018, almost 7000 people were accommodated in the Dublin region, representing over $70 \%$ of the national homeless population. The DRHE commissioned this study.

\section{Patient and public involvement}

Neither patients nor the public participated in this study

The European Typology of Homelessness and Housing Exclusion (ETHOS) identifies four main categories of homelessness: roofless, houseless, insecure housing, inadequate housing (FEANTSA). The DRHE are responsible for all roofless persons and all houseless persons accommodated in emergency accommodation. The ETHOS typology also includes domestic violence and immigrant accommodation under the houseless category but in an Irish context these services are funded under different government departmental funding streams. Consequently the Pathway Accommodation and Support System (PASS) data is restricted to services funded under Section 10 (of the Housing Act, 1988 enables local authorities to provide funding to voluntary bodies for the provision of emergency accommodation and long term housing for people who are homeless) of the Housing Act, 1988 which enables local authorities to provide funding to voluntary bodies for the provision of emergency accommodation and long term housing for people who are homeless.

\section{Homeless population}

Data on the homeless population were provided by the DRHE. The DRHE introduced a new method of counting homeless people, the PASS, in 2011. The PASS is a live, shared client database with bed management and support planning functions. PASS provides live information about homeless presentations and bed occupancy within the Dublin area and has been rolled out nationally to all regions. The introduction of the PASS has led to greater efficiency and an improved approach to collecting essential data on both presentation and service utilisation in the homeless services. PASS data is used to generate the national monthly and quarterly figures reported and published by the Department of Housing, Planning, Community and Local Government so that there is a single agreed methodology to enumerating the homeless population in Ireland (see supplementary table 1).

\section{Homeless deaths}

The DRHE records of death consisted mostly of death notifications recorded on a standardised form developed by the DRHE that required service providers to notify the DRHE of all deaths in services. However, in some instances, homeless service providers did not use the form and simply reported deaths in an email or facsimile. A three-phase design was necessary to validate the death data in the homeless population.

Phase 1-Validation consisted of validating the dataset based on the death notifications maintained by DRHE. Data from DRHE records $(n=180)$ were used to extract name, date of birth, date of death and place of death. These data were the minimal data required to find and view a death certificate in the General Registrar's Office (GRO). The GRO hold records of all births, deaths and marriages registered in Ireland. The purpose was twofold: (1) validate the death and (2) obtain a cause of death. The study also utilised the records at the Dublin City Coroner's Office to validate deaths of cases with outstanding inquests. At the end of phase 1, 172 of the 180 deaths were validated. Deaths that were not validated were not included in the study.

Phase 2-Audit consisted of meeting with a number of key agencies that had reported deaths to the DRHE during the study period. The main purpose of the audit was to 
cross-check homeless agencies records against homeless death notifications. During site visits, it became apparent that agencies reported and maintained records of deaths of service users differently across the sector. Some agencies reported only the death of a service user who died in their service; others reported the death of a service user who died in another agency but who was also accessing their services at the time, while other agencies reported the death of a known homeless person. In the effort to compile as comprehensive a picture as possible, an audit of records was carried out. Participating agencies included in the study were requested to return a copy of the death records of service users who had died during the study period. In addition, it was decided that the research team would meet with two hospice services that were named as the place of death on a number of death notifications. These two services also took part in the audit.

Phase 3-Reconciliation consisted of cross-checking the audit figures against the DRHE death notifications. As a result, $\mathrm{n}=29$ deaths were further verified as having occurred between 2011 and 2015. These additional cases were validated as per phase 1: either in GRO or Coroners records and included in the dataset.

\section{General population}

We acquired age and gender census data for Dublin for the census year 2011 from the Central Statistics Office (CSO) ${ }^{30}$ In addition, we acquired the intercensal estimates for 2012-2015 (see online supplementary table 2). Mortality data by age and gender for the years 2011-2015 inclusive was supplied by the CSO (see online supplementary table 3 ).

Standardised mortality ratios (SMRs) were calculated for each calendar year overall, and for males and females separately by using the indirect standardisation method. Where date of birth (age) of homeless persons was not known, it was distributed across the data in the same proportion as where the age was known. The general population of Dublin was used as reference population. Age-specific mortality rate was calculated for the general population of Dublin using the census data. This rate was used to calculate the expected number of deaths in the homeless population (by multiplication of the number of homeless people in each age group by the reference mortality rate for that age group), for each age group. Addition of deaths across all age groups gave us the total number of expected deaths in the homeless population. SMR was calculated as the ratio of observed to the expected number of deaths among homeless.

\section{RESULTS}

A total of 201 deaths of homeless people, which occurred between 2011 and 2015, were included in the current study (table 1 ). The median age at death was 42 years (males 44 years and females 36 years).

\section{Standardised mortality ratios}

SMRs for homeless men ranged from 3 to 10 (table 2), compared with Dublin males in the general population.
Table 1 Verified deaths in the homeless population in Dublin 2011-2015 by age and gender

\begin{tabular}{|c|c|c|c|c|c|c|c|}
\hline Gender & $\begin{array}{l}\text { Age } \\
\text { group }\end{array}$ & 2011 & 2012 & 2013 & 2014 & 2015 & Total \\
\hline \multirow[t]{4}{*}{ Male } & $18-24$ & 1 & 1 & 5 & 3 & 2 & 12 \\
\hline & $25-44$ & 7 & 9 & 10 & 14 & 26 & 66 \\
\hline & $45-64$ & 4 & 14 & 8 & 13 & 19 & 58 \\
\hline & $65+^{*}$ & 1 & 2 & 3 & 4 & 4 & 14 \\
\hline \multicolumn{2}{|c|}{ Missing data } & 0 & 0 & 0 & 3 & 3 & 6 \\
\hline & $\begin{array}{l}\text { Male } \\
\text { total }\end{array}$ & 13 & 26 & 26 & 37 & 54 & 156 \\
\hline \multirow[t]{5}{*}{ Female } & $\begin{array}{l}\text { Age } \\
\text { group }\end{array}$ & 2011 & 2012 & 2013 & 2014 & & Total \\
\hline & $18-24$ & 0 & 0 & 1 & 0 & 0 & 1 \\
\hline & $25-44$ & 2 & 4 & 6 & 10 & 6 & 28 \\
\hline & $45-64$ & 1 & 3 & 0 & 1 & 3 & 8 \\
\hline & $65+$ & 1 & 1 & 2 & 1 & 0 & 5 \\
\hline \multicolumn{2}{|c|}{ Missing data } & 0 & 0 & 0 & 0 & 3 & 3 \\
\hline & $\begin{array}{l}\text { Female } \\
\text { total }\end{array}$ & 4 & 8 & 9 & 12 & 12 & 45 \\
\hline \multicolumn{2}{|c|}{ Grand total } & 17 & 34 & 35 & 49 & 66 & 201 \\
\hline
\end{tabular}

*Age categories 45-64 and 65+ have been collapsed in the current table due to small numbers and thus, potentially, identifiable deaths.

For homeless women the SMRs ranged from 6 to 10 . The highest ratio for females was in 2012, whereas 2015 was highest ratios for males.

The majority of homeless people died in hospital or in a homeless service. Just over 10\% ( $\mathrm{n}=22)$ of people died outdoors (table 3 ).

\section{Cause of death}

Cause of death was confirmed for 195 cases (online supplementary table 4) and $n=6$ are awaiting inquests.

Drug and alcohol were among the leading cause of death for this cohort (table 4) accounting for more than one third of all verified deaths $(38.4 \%)$. In addition, in a further 43 , cases alcohol and drugs were implicated. Thus, in $58.7 \%(118 / 195)$ of all verified causes of death, drugs and/or alcohol were implicated. Moreover, drugs, particularly opioids, were implicated in more than half of drug related cases.

\section{DISCUSSION}

We examined 201 deaths that occurred among homeless people between 2011 and 2015. Mortality rates were much higher among homeless people compared with the general population: for men SMRs were between 3 and 10 times higher for homeless women the SMRs ranged from 6 to 10 times higher. These are however, in line with international findings. ${ }^{17} 18$ Just over $10 \%$ of deaths occurred 
Table 2 Standardised mortality ratios (SMRs) 2011-2015

\begin{tabular}{|c|c|c|c|c|c|c|c|c|c|}
\hline \multirow[b]{2}{*}{ Year } & \multicolumn{3}{|l|}{ Males } & \multicolumn{3}{|l|}{ Females } & \multicolumn{3}{|c|}{ Both genders } \\
\hline & Observed $^{*}$ & Expected $\dagger$ & SMR & Observed & Expected & SMR & Observed* & Expected $†$ & SMR \\
\hline 2011 & 13 & 4.9 & 2.7 & 4 & 0.65 & 6.2 & 17 & 5.55 & 3.1 \\
\hline 2013 & 26 & 6.1 & 4.3 & 9 & 1 & 9 & 35 & 7.1 & 4.9 \\
\hline 2014 & 37 & 6.4 & 5.8 & 12 & 1.3 & 9.2 & 49 & 7.7 & 6.4 \\
\hline Total & 156 & 28.6 & 5.5 & 45 & 5.05 & 8.9 & 201 & 33.65 & 6.0 \\
\hline
\end{tabular}

${ }^{*}$ Number of observed deaths in the homeless population.

†Number of expected deaths (calculate expected number of deaths among homeless as: mortality rate in general pop multiplied by the number of homeless people per age group).

outdoors, a low figure in comparison to figures reported in the international literature. ${ }^{31}$

The causes of death for homeless individuals are different from those of the general population: drug and alcohol related deaths accounted for more than one third of deaths in homeless individuals, a finding that is also consistent with the current body of research. ${ }^{17}$ Moreover, opioids accounted for most of these deaths. The majority of drug related deaths in Ireland ${ }^{32}$ and the $\mathrm{UK}^{33} 34$ are from opioid overdose. The high percentage of potentially avoidable deaths among homeless people from opioid overdose presents an opportunity for the development of possible preventative strategies. For example, public health initiatives such as naloxone to prevent and reverse opioid drug overdose should be considered and expanded to reduce the number of overdose fatalities in this population.

A number of studies in homeless populations have noted the emergence of an ageing population. ${ }^{4536}$ For example, in the USA the median age of the homeless population at death is 50 years. ${ }^{4}$ Similarly, Neilsen et al in Denmark report a mean age of 50 at death. The median age at death for homeless people in Dublin was 43 years old, with the median age at death for homeless women even lower at 41 . Furthermore, in the current study only 12 deaths in people 65 and over emerged from the data.

Acquiring and validating mortality data is a complex task and data such as date of birth and legal name is at times unknown. Thus, the validation of the vast majority

\begin{tabular}{|c|c|c|}
\hline $\begin{array}{l}\text { Place of deaths } \\
2011-2015\end{array}$ & $\mathbf{N}$ & $\%$ \\
\hline Hospital & 100 & 49.7 \\
\hline Homeless services & 60 & 29.7 \\
\hline Outdoors & 22 & 10.9 \\
\hline Hospice & 8 & 4.4 \\
\hline Prison & 1 & 0.4 \\
\hline Private residence & 10 & 4.9 \\
\hline Total & 201 & 100 \\
\hline
\end{tabular}

of reported deaths is a major strength of the study. The audit cycle proved to be quite simple and effective. The findings highlighted several discrepancies in reported deaths throughout the recording system. It highlighted the need for agencies reporting a death to the DRHE to improve current reporting practices. In addition, the PASS emerged as highly effective in recording the daily activity of service users. In addition, it offers consistency regarding homeless status.

Walsh suggest that apart from the scale of homelessness in the capital, the Dublin homeless population does not differ substantially in demographics when compared with other counties in Ireland. ${ }^{37}$ Thus, the current findings may be generalisable to the whole of Ireland. Similarly, the demographics as well as the causes of death indicate similarities between the current study and other international cohorts in terms of age, gender and SMRs. ${ }^{711} 12$

The current study data had a number of limitations. A small number of the deaths in the current study were unverifiable and excluded from the analysis. Data gathering was challenging because data in this population is often incomplete and many individuals utilising homeless services use an alias rather than legal name. Record keeping varied significantly between agencies and some discrepancies existed between agency records and deaths reported to the DRHE.

\section{CONCLUSION}

In conclusion, this study demonstrates dramatically higher mortality ratios among men and women who were

\begin{tabular}{lc}
\hline Table 4 & Drug and alcohol related deaths, \\
\hline Drug and alcohol related deaths & Total \\
\hline Drugs & 71 \\
\hline Alcohol & 2 \\
Both drugs and alcohol & 2 \\
Total & 75 \\
Deaths where drugs were antecedent & 43 \\
Total & 118 \\
\hline
\end{tabular}


homeless. Overdose from substance use was a critical factor in more than one third of verified deaths included in the current study, with opioids being over-represented. Homeless people are notably more likely to die by overdose than the general population. These findings should be taken into account when developing interventions to prevent mortality among homeless populations.

Contributors $\mathrm{Jl}$ and JB developed and directed the study. JB and $\mathrm{Jl}$ conceived and designed the survey questions. $\mathrm{JI}$ coordinated data collection and $\mathrm{Jl}, \mathrm{BOH}$ and $\mathrm{AH}$ carried out data cleaning and cross-validation. JHHI and LZ performed the statistical analyses. JI drafted the manuscript. JI, JB, LZ, BOH and AH contributed to the final draft of the paper.

Funding This work was supported by the Dublin Region Homeless Executive and the Health Service Executive [Grant No N/A].

Competing interests None declared.

Patient consent for publication Not required.

Ethics approval The study received ethical approval by Ethics Committee at the Faculty of Health Sciences, Trinity College Dublin.

Provenance and peer review Not commissioned; externally peer reviewed. Data sharing statement № additional data available.

Open access This is an open access article distributed in accordance with the Creative Commons Attribution Non Commercial (CC BY-NC 4.0) license, which permits others to distribute, remix, adapt, build upon this work non-commercially, and license their derivative works on different terms, provided the original work is properly cited, appropriate credit is given, any changes made indicated, and the use is non-commercial. See: http://creativecommons.org/licenses/by-nc/4.0/.

\section{REFERENCES}

1. North CS, Eyrich KM, Pollio DE, et al. Are rates of psychiatric disorders in the homeless population changing? Am J Public Health 2004;94:103-8.

2. Caton CL, Dominguez B, Schanzer B, et al. Risk factors for longterm homelessness: findings from a longitudinal study of first-time homeless single adults. Am J Public Health 2005;95:1753-9.

3. Aldridge RW, Story A, Hwang SW, et al. Morbidity and mortality in homeless individuals, prisoners, sex workers, and individuals with substance use disorders in high-income countries: a systematic review and meta-analysis. Lancet 2018;391.

4. Fazel S, Geddes JR, Kushel M. The health of homeless people in high-income countries: descriptive epidemiology, health consequences, and clinical and policy recommendations. Lancet 2014;384:1529-40.

5. Kneebone RD, Bell M, Jackson N, et al. Who Are The Homeless? Numbers, Trends and Characteristics Of Those Without Homes in Calgary, 2015.

6. Koegel P, Burnam MA, Farr RK. The prevalence of specific psychiatric disorders among homeless individuals in the inner city of Los Angeles. Arch Gen Psychiatry 1988;45:1085-92.

7. Drake RE, Mueser KT, Clark RE, et al. The course, treatment, and outcome of substance disorder in persons with severe mental illness. Am J Orthopsychiatry 1996;66:42-51.

8. Nielsen SF, Hjorthøj CR, Erlangsen A, et al. Psychiatric disorders and mortality among people in homeless shelters in Denmark: a nationwide register-based cohort study. Lancet 2011;377:2205-14.

9. Fazel S, Khosla V, Doll H, et al. The prevalence of mental disorders among the homeless in western countries: systematic review and meta-regression analysis. PLoS Med 2008;5:e225.

10. Tsemberis S, Gulcur L, Nakae M. Housing First, consumer choice, and harm reduction for homeless individuals with a dual diagnosis. Am J Public Health 2004;94:651-6.

11. Kertesz SG, Crouch K, Milby JB, et al. Housing first for homeless persons with active addiction: are we overreaching? Milbank $Q$ 2009;87:495-534.
12. Mitka M. Chronic homeless in intervention spotlight. JAMA 2006;295:2344-5.

13. Beck AT, Hollon SD, Young JE, et al. Treatment of depression with cognitive therapy and amitriptyline. Arch Gen Psychiatry 1985;42:142.

14. Brudney K, Dobkin J. Resurgent tuberculosis in New York City. Human immunodeficiency virus, homelessness, and the decline of tuberculosis control programs. Am Rev Respir Dis 1991;144:745-9.

15. Gelberg L, Gallagher TC, Andersen RM, et al. Competing priorities as a barrier to medical care among homeless adults in Los Angeles. Am J Public Health 1997;87:217-20.

16. Fein $O$. The influence of social class on health status. J Gen Intern Med 1995;10:577-86.

17. Baggett TP, Hwang SW, O'Connell JJ, et al. Mortality among homeless adults in Boston: shifts in causes of death over a 15-year period. JAMA Intern Med 2013;173:189-95.

18. Hwang SW, Wilkins R, Tjepkema M, et al. Mortality among residents of shelters, rooming houses, and hotels in Canada: 11 year follow-up study. BMJ 2009;339:b4036.

19. Lester $\mathrm{H}$, Wright $\mathrm{N}$, Heath I, et al. Developments in the provision of primary health care for homeless people. Br J Gen Pract 2002;52:91.

20. Beijer U, Andréasson A, Agren G, et al. Mortality, mental disorders and addiction: a 5-year follow-up of 82 homeless men in Stockholm. Nord J Psychiatry 2007;61:363-8.

21. Feodor Nilsson S, Hjorthøj CR, Erlangsen A, et al. Suicide and unintentional injury mortality among homeless people: a Danish nationwide register-based cohort study. Eur J Public Health 2014;24:50-6.

22. Moore CE, Warren R, Maclin SD. Head and neck cancer disparity in underserved communities: probable causes and the ethics involved. $J$ Health Care Poor Underserved 2012;23:88-103.

23. Moore CE, Durden F. Head and neck cancer screening in homeless communities: HEAL (Health Education, Assessment, and Leadership). J Natl Med Assoc 2010;102:811-6.

24. Cheung AM, Hwang SW. Risk of death among homeless women: a cohort study and review of the literature. CMAJ 2004;170:1243-7.

25. O'Carroll A. Making Sense of Street Chaos: An Ethnographic Exploration of the Health Service Usage of Homeless People in Dublin: University of Bath, 2015.

26. Harvey B, O'Sullivan E, McCafferty J-M. Critical perspectives on Irish homelessness. Perspectives on Irish Homelessness: Past, Present and Future, 2008.

27. Maycock P, Corr M-L. Young people's homeless and housing pathways: key findings from a 6-year qualitative longitudinal study. Dublin: Dublin Region Homeless Executive, 2013.

28. Vuillermoz C, Aouba A, Grout L, et al. Estimating the number of homeless deaths in France, 2008-2010. BMC public health 2014;14:1.

29. Copeland L, Budd J, Robertson JR, et al. Changing patterns in causes of death in a cohort of injecting drug users, 1980-2001. Arch Intern Med 2004;164:1214-20.

30. Ofiice CS. Homelessness: A special Census report. Dublin: Central Statistics Office, 2012.

31. O'Connell JJ. Premature mortality in homeless populations: A review of the literature. Nashville, TN: National Health Care for the Homeless Council, 2005.

32. Board HR. Drug-related deaths and deaths among drug users in Ireland: 2013 figures from the National Drug-Related Deaths Index: Dublin: Health Research Board, 2015.

33. Darke S, Zador D. Fatal heroin 'overdose': a review. Addiction 1996;91:1765-72.

34. Hickman M, Madden P, Henry J, et al. Trends in drug overdose deaths in England and Wales 1993-98: methadone does not kill more people than heroin. Addiction 2003;98:419-25.

35. Bazari A, Patanwala M, Kaplan LM, et al. 'The thing that really gets me is the future': Symptomatology in older homeless adults in the HOPE HOME Study. J Pain Symptom Manage 2018;56:195-204.

36. Hahn JA, Kushel MB, Bangsberg DR, et al. BRIEF REPORT: the aging of the homeless population: fourteen-year trends in San Francisco. $J$ Gen Intern Med 2006;21:775-8.

37. Walsh K. Homelessness Ageing and Dying. Homelessness, Ageing and Dying. Exploratory research looking at the needs of older people who are homeless as they age, and are faced with the issues of serious ill- health and dying, 2013. 
Correction: Five-year standardised mortality ratios in a cohort of homeless people in Dublin

Ivers J, Zgaga L, O’Donoghue-Hynes B, et al. Five-year standardised mortality ratios in a cohort of homeless people in Dublin BMJ Open 2019;9:e023010. doi: 10.1136/ bmjopen-2018-023010

This article was previously published with an error.

Currently on Page 3 in Results, the article reads:

A total of 201 deaths of homeless people, which occurred between 2011 and 2015, were included in the current study (table 1 ). The median age at death was 42 years (males 44 years and females 36 years).

This should actually read:

A total of 201 deaths of homeless people, which occurred between 2011 and 2015, were included in the current study (table 1 ). The mean age at death was 42 years (males 44 years and females 36 years). The median is reported later.

Open access This is an open access article distributed in accordance with the Creative Commons Attribution Non Commercial (CC BY-NC 4.0) license, which permits others to distribute, remix, adapt, build upon this work non-commercially, and license their derivative works on different terms, provided the original work is properly cited, appropriate credit is given, any changes made indicated, and the use is non-commercial. See: http://creativecommons.org/licenses/by-nc/4.0/.

C Author(s) (or their employer(s)) 2019. Re-use permitted under CC BY-NC. No commercial re-use. See rights and permissions. Published by BMJ.

BMJ Open 2019;9:e023010corr1. doi:10.1136/bmjopen-2018-023010corr1

A) Check for updates 